\title{
BENTUK LOYALITAS DONATUR PADA ORGANISASI FILANTROPI
}

\author{
Tanti Handriana \\ Fakultas Ekonomi dan Bisnis Universitas Airlangga \\ handriana_tanti@yahoo.com
}

\begin{abstract}
Abstrak
Baik organisasi laba maupun nonlaba, keduanya membutuhkan relasi yang baik dengan pelanggan (donatur). Relasi yang terjalin di antara donatur dan organisasi filantropi merupakan kunci untuk meraih keberhasilan dan kelanggengan organisasi. Tujuan dari artikel ini adalah untuk menggali dan menganalisis informasi tentang bentuk-bentuk loyalitas pelanggan/donatur pada organisasi filantropi. Riset ini menggunakan metode penelitian kualitatif, dengan menggunakan teknik pengumpulan data berupa wawancara mendalam (indepth interview) pada para donatur organisasi filantropi. Sebagai pembanding (tri angulasi), maka dilakukan wawancara mendalam juga dengan pakar manajemen pemasaran serta organisasi filantropi. Hasil riset menunjukkan bahwa donatur yang memiliki komitmen relasional yang tinggi, kepercayaan yang besar pada organisasi, dan rasa terima kasih pada organisasi filantropi cenderung memiliki perilaku loyal pada organisasi filantropi di mana mereka selama ini mendonasikan uangnya. Adapun bentuk-bentuk loyalitas yang mereka lakukan antara lain adalah berupa kemauan untuk terus memberikan sumbangan di organisasi filantropi, apabila mendapat rezeki yang lebih banyak maka jumlah donasi yang mereka berikan juga akan ditingkatkan, tidak akan beralih ke organisasi lainnya, rela/berkenan untuk memberikan sumbangan tenaga dan fikiran mereka apabila organisasi membutuhkannya, serta tidak sungkan-sungkan untuk memberikan masukan demi kebaikan dan masa depan organisasi tersebut. Dengan demikian, hasil riset ini mendukung konsep relationship marketing dan konsep loyalitas di organisasi non laba.
\end{abstract}

Keywords: komitmen relasional, kepercayaan, rasa terima kasih, loyalitas, relationship marketing

\section{PENDAHULUAN}

Hampir di sebagian besar di kota-kota di Indonesia kita sering melihat para peminta-minta berkeliaran di sekitar traffic light. Hal ini kemungkinan tidak akan terjadi, apabila seluruh masyarakat Indonesia memberikan sumbangan mereka pada organisasi filantropi yang memang beroperasi untuk menampung sumbangan dari masyarakat dan menyalurkannya pada orang-orang yang membutuhkan.

Sementara itu, fenomena adanya penurunan jumlah donasi yang diterima oleh organisasi filantropi bersumber dana dari luar negeri terjadi dari tahun ke tahun. 
Data yang dihimpun oleh Public Interest Research and Advocacy Center (PIRAC) menunjukkan bahwa pada tahun 2007 jumlah bantuan luar negeri Rp3,7 triliun turun menjadi Rp2,3 triliun pada tahun 2008. Sementara itu, pada tahun 2010 lebih kecil lagi, bantuan dari luar negeri hanya sekitar Rp900 miliar. Oleh karena itu, organisasi-organisasi ini mengandalkan sumbangan yang berasal dari masyarakat (para penyumbang). Adapun besarnya potensi sumbangan masyarakat Indonesia yang lebih dari Rp 12,3 triliun per tahun, baru sekitar 10\% yang berhasil digalang oleh lembaga-lembaga di Indonesia. Artinya, potensi yang seperti raksasa ini masih tertidur pulas dan perlu untuk dibangunkan (http://sekolahfundraising. wordpress. com/ diakses 16/9/2014).

Dalam menjalin suatu hubungan, kepercayaan pada mitra relasi merupakan faktor yang sangat dibutuhkan keberadaannya. Venable et al. (2005), Sargeant dan Lee (2002) mengungkapkan bahwa kepercayaan dan pertukaran sosial berperan penting dalam keputusan donatur apakah akan mendonasikan uang, waktu, barang atau jasa pada organisasi. Selain kepercayaan, komitmen untuk berhubungan juga merupakan variabel yang menjadi penentu dalam suatu relasi. Kepercayaan dan komitmen merupakan konsep kunci dalam teori pertukaran sosial dan literatur relationship marketing (Lou dan Donthu 2007; Handriana, 2010; Handriana dan Lestari, 2013). Sementara itu, Palmatier et al. (2009) menguji kedudukan variabel rasa terima kasih pelanggan sebagai variabel mediator dalam proses relationship marketing. Demikian juga dengan Handriana dan Lestari (2013) mendapatkan temuan bahwa rasa terima kasih mempengaruhi kepercayaan, dan tidak mempengaruhi niat penyumbang untuk menyumbang kembali di organisasi filantropi. Oleh karena itu, hal ini menarik untuk digali lebih dalam.

Penelitian ini akan menggali informasi secara mendalam serta menganalisis konsekuensi dari rasa terima kasih, kepercayaan, dan komitmen relasional pada oganisasi filantropi. Dengan demikian, urgensi dari penelitian ini adalah dalam lingkup teori untuk mengembangkan teori relationship marketing khususnya untuk organisasi nonlaba, serta dalam lingkup praktis, hasil riset ini dapat diimplementasikan oleh organisasi filantropi untuk menjalin relasi jangka panjang dengan para penyumbangnya. Dengan demikian permasalahan yang diangkat 


\section{Jurnal Manajemen Teori dan Terapan \\ Tahun 8. No. 3, Desember 2015}

dalam studi di adalah bagaimanakah bentuk-bentuk loyalitas donatur/penyumbang pada organisasi filantropi?

\section{KAJIAN TEORETIS}

\section{Teori Pertukaran Sosial}

Proposisi yang dikemukakan oleh Homans (1968) bahwa seseorang dalam hubungan pertukaran dengan pihak lain akan mengharapkan imbalan yang diterima sebanding dengan pengorbanan yang telah dikeluarkannya dan keuntungan yang diterima harus sebanding dengan investasinya. Dengan demikian terlihat bahwa prinsip dasar pertukaran sosial adalah distributive justice yakni aturan bahwa sebuah imbalan harus sebanding dengan investasi.

Perspektif teori pertukaran sosial menjelaskan struktur sosial sebagai suatu proses pertukaran yang dinegosiasikan di antara pihak-pihak yang terlibat, berdasarkan pada harapan akan hasil dalam suatu tindakan pengembalian yang sepadan, dan bahwa relasi manusia dibentuk oleh penggunaan analisis biaya-manfaat subjektif dan dengan membandingkan alternatif (Gouldner, 1960). Sementara itu, Blau (1964) menjelaskan bahwa pertukaran sosial cenderung menimbulkan keinginan untuk memenuhi kewajiban, rasa terima kasih, dan kepercayaan seseorang. Pertukaran sosial membawa nilai intrinsik yang terdapat dalam hubungan itu sendiri dan melebihi nilai ekstrinsik, nilai ekonomi barang/jasa yang dipertukarkan (Luo dan Donthu, 2007). Teori ini dikembangkan oleh pakar psikologi John Thibaut dan Harlod Kelley, serta pakar sosiologi George Homans, dan Peter Blau.

\section{Relationship Marketing}

Ide awal dalam pengembangan pemikiran relationship marketing merupakan suatu kontinum perelasian pelanggan, yakni dari orientasi transaksional ke relasional (Dwyer et al., 1987). Dalam relationship marketing, terlihat relasi yang begitu dekat dan saling membutuhkan di antara pihak-pihak yang terlibat, bahkan Dwyer et al. (1987) mengandaikan relationship marketing sebagai bentuk "perkawinan pembeli-penjual" layaknya manfaat dalam relasi suami-istri dalam hal kerjasama, keakraban, berkreasi bersama, pembimbingan, pertumbuhan individu, saling berbagi dalam merawat peralatan rumah tangga, dukungan sosial, pilihan seksual dan kedekatan sosial, tanggung jawab bersama, 
keinginan untuk saling merawat dan memerhatikan, demikian juga dengan kedekatan antara pembeli dan penjual dalam konsep relationship marketing.

Relationship marketing telah didefinisikan dalam berbagai definisi. Yang bisa dikatakan sebagai definisi paling awal adalah yang dikemukakan oleh Berry (1983) dalam Morgan dan Hunt (1994) bahwa relationship marketing merupakan strategi untuk menarik, memelihara, dan mempererat hubungan dengan pelanggan. Menurut Gronross (1994), relationship marketing bertujuan untuk membentuk, memelihara, dan mempererat hubungan dengan pelanggan dan mitra lain dengan keuntungan dapat terwujudnya tujuan masing-masing pihak yang terkait. McCort (1994) mengatakan bahwa relationship marketing pada organisasi nonlaba ditujukan untuk mencari hubungan jangka panjang dengan pelanggan, sehingga meningkatkan loyalitas para penyumbang.

\section{METODE PENELITIAN}

Metode penelitian yang digunakan dalam riset ini adalah metode penelitian kualitatif, dengan menggunakan pendekatan grounded theory, dengan pengumpulan menggunakan teknik wawancara mendalam (in-depth interview) kepada para informan. Adapun informan yang terlibat dalam penelitian ini adalah para penyumbang organisasi filantropi, dan juga dari dosen/pakar manajemen pemasaran, serta para pengelola organisasi filantropi. Penggunakan pendekatan riset kualitatif dianggap tepat dalam penelitian ini, mengingat isu permasalahan yang diangkan dalam riset ini adalah untuk memahami dan mengeksplorasi, bukan hanya sekedar menguji hubungan/pengaruh suatu variabel terhadap variable-variabel lainnya. Dalam penelitian ini, terdapat 3 (tiga) kelompok informan yang akan diwawancara secara mendalam. Adapun ke tiga kelompok tersebut antara lain: (1) para donatur, yaitu orang-orang yang memberikan sumbangan berupa uang kepada organisasi filantropi; (2) para pengelola organisasi filantropi; dan (3) para pakar/dosen manajemen pemasaran. Adapun teknik sampling yang digunakan adalah snowball sampling dan akan dilakukan penghentian pencarian informan, apabila sudah tidak didapatkan lagi informasi tambahan atau bisa dikatakan telah mencapai titik saturation.

\section{Validasi penelitian kualitatif}




\section{Jurnal Manajemen Teori dan Terapan \\ Tahun 8. No. 3, Desember 2015}

Dalam penelitian kualitatif perlu dilakukan validasi, salah satu caranya adalah dengan melakukan triangulasi (Shenton, 2004). Triangulasi terutama dilakukan dengan triangulasi metode, yaitu proses triangulasi adengan membandingkan antara hasil yang diperoleh dari penelitian kuantitatif dengan hasil yang diperoleh dari penelitian kualitatif lainnya. Hasil penelitian dikatakan valid apabila didapatkan konfirmasi hasil (Guion, 2002).

Validasi lain adalah dengan penggunaan informan lebih dari satu sumber. Seperti dikemukakan oleh Shenton (2004) bahwa konsep atau tema yang diidentifikasi harus teridentifikasi berdasarkan informasi lebih dari satu informan atau sumber. Dalam riset ini dilakukan validasi melalui triangulasi dengan menggunakan informan lebih dari satu sumber, yaitu dari pakar/dosen menajamen pemasaran dan para pengelola organisasi filantropi.

\section{Analisis Data}

Hasil wawancara mendalam dengan para informan selanjutnya akan didiskripsikan dan dianalisis secara mendalam. Adapun hasil dari analisis data yang berupa hasil wawancara tersebut diharapkan dapat memberikan kontribusi bagi keberlangsungan organisasi filantropi dalam operasionalnya. Selain itu, hasil dari analisis juga diharapkan dapat memberikan kontribusi bagi pengembangan ilmu pengetahuann, khususnya manajemen pemasaran, khususnya dalam membangun/mengembangkan sebuah teori terkait dengan relationship marketing bagi organisasi nonlaba.

\section{HASIL DAN PEMBAHASAN}

\section{Gambaran informan}

Dalam studi ini, informan terdiri atas tiga pihak. Informan pertama adalah para donatur yang memberikan sumbangan berupa uang kepada organisasi filantropi, sebanyak 7 orang. Informan ke dua adalah para pengelola organisasi filantropi sebanyak 2 orang, sedangkan informan ke tiga adalah pakar/dosen manajemen pemasaran sebanyak 2 orang.

\section{Hasil Indepth Interview}

Pada penelitian ini, hasil wawancara secara mendalam dengan para donatur, wawancara dengan para pengelola filantropi, dan terakhir wawancara dengan dosen/pakar manajemen pemasaran akan digabungkan sama sama 
lain berdasar kemiripan atau kesamaan pendapat mereka mengenai rasa terima kasih, kepercayaan, komitmen relasional, dan loyalitas donatur pada organisasi filantropi.

\section{a. Rasa Terima Kasih Donatur pada Organisasi Filantropi}

Rasa terima kasih yang ada di benak nampaknya banyak dirasakan oleh para informan yang berupa para donatur seperti berikut ini:

"Rasa terima kasih memang bisa muncul, tapi menurutku tidak semua donatur memiliki rasa terima kasih itu. Kemungkinan hanya donaturdonatur yang sudah merasa bahwa organisasi telah bekerja sesuai dengan harapan mereka. Kalau aku sendiri juga merasa bahwa organisasi telah melakukan pekerjaannya dengan baik, sehingga rasa terima kasihku pada organisasi tersebut juga besar." (H, pria, 49 tahun, wiraswasta)

"Saya sudah menjadi donatur di organisasi ini kurang lebih selama 15 tahun, dan saya merasa bahwa organisasi ini telah sesuai dengan apa yang saya inginkan dan saya harapkan, sehingga rasa terima kasih juga muncul dalam benak saya." (E, wanita, 43 tahun, karyawati swasta)

"Rasa terima kasih saya pada yayasan ini timbul karena dengan adanya yayasan ini saya tidak perlu repot-repot untuk memberikan vang sumbangan saya ke orang-orang yang membutuhkan secara langsung, tapi cukup dengan mengandalkan kinerja dari yayasan ini saya yakin bahwa uang yang saya sumbangkan itu benar-benar tersalurkan ke orang-orang yang membutuhkan. Hal ini tentunya membuat saya semakin percaya dengan keandalan dari yayasan ini." ( $S$, wanita, 30, dokter gigi)

"Saya juga merasa berterima kasih pada organisasi ini, karena melalui organisasi ini saya merasa telah menjalankan salah satu amalan seperti yang diajarkan dalam agama saya. Dan saya juga merasa sudah menjadi orang yang agak baik, agaknya dalam tanda kutip, karena juga menjalankan peraturan pemerintah untuk tidak memberikan sumbangan di jalan-jalan, seperti kita tahu bahwa pemerintah juga menganjurkan kita untuk memberikan sumbangan ke organisasi-organisasi filantropi saja. dengan menjalankan perintah agama dan perintah pemerintah, saya merasa telah belajar menjadi manusia yang baik." (SY, wanita, 30 tahun, dokter gigi)

"Sebagai umat muslim saya ini merasa telah menjalankan salah satu perintah agama saya, yaitu untuk mengeluarkan zakat, infak dan juga sedekah pada orang-orang yang kurang beruntung. Dengan adanya yayasan yang bersedia menyalurkan zakat, infak, dan sedekah ini membuat saya merasa berterima kasih, karena untuk urusan yang terkait 


\section{Jurnal Manajemen Teori dan Terapan Tahun 8. No. 3, Desember 2015}

dengan zakat, infak, dan sedekah tersebut sudah ditangani oleh ahlinya, yaitu organisasi filantropi tersebut." (DP, pria, 35 tahun, PNS)

"Rasa terima kasih saya pada organisasi filantropi disebabkan oleh perlakuan atau layanan yang telah saya terima selama saya menjadi donatur di organisasi ini." (RS, pria, 39 tahun, karyawan swasta)

"Perasaan senang dari para donatur atas apa yang pelayanan yang telah diberikan oleh orang-orang yang ada di organisasi filantropilah yang membentuk rasa terima kasih para donatur ini. Dengan rasa tersebut akan semakin menguatkan hubungan yang dijalin oleh donatur dengan organisasi. Artinya, mereka akan rutin memberikan sumbangan vangnya ke organisasi, serta memberikan sumbangan yang lebih besar dari biasanya apabila mereka mendapatkan rezeki yang lebih banyak atau lebih besar dari biasanya." ( $\mathrm{H}$, pria, 52 tahun, pengelola organisasi filantropi / wiraswasta)

"Rasa terima kasih yang muncul dalam benak donatur adalah sebagai akibat dari effort dan segala aktivitas yang telah dilakukan oleh organisasi filantropi. Menurut saya, rasa terima kasih ini sangat penting, karena rasa ini tidak bisa dibuat-buat oleh donatur, rasa terima kasih ini merupakan bentuk ekspresi yang tidak bisa dibuat-buat. Dengan rasa terima kasih yang ada di hati para donatur atas apa yang telah dilakukan oleh organisasi akan menjadikan sebagai ikatan emosional antara donatur dan organisasi." (L, wanita, 61 tahun, pengelola organisasi filantropi dan Dirut perusahaan)

"Rasa terima kasih dan rasa senang memang sering muncul manakala seseorang mendapatkan sesuatu, baik itu berupa barang maupun jasa dari pihak lain. Demikian juga dalam konteks hubungan antara penyumbang atau donatur dengan organisasi filantropi tempat di mana dia memberikan sumbangannya, rasa terima kasih ini bisa muncul karena penyumbang merasa bahwa organisasi tersebut telah menjalankan tugas dan fungsinya dengan baik, yaitu bersedia menerima dan menyalurkan sumbangan kepada pihak-pihak/masyarakat yang kurang mampu. Dengan telah dilaksanakan tugas-tugas tersebut dengan baik oleh organisasi filantropi, hal ini akan menimbulkan kelegaan bagi penyumbang tersebut karena dia merasa telah melaksanakan kewajibannya dalam menjalankan syariah agama misalnya. Dengan adanya rasa terima kasih ini, sangat mungkin akan menyebabkan dia untuk menyumbang di organisasi tersebut akan untuk seterusnya." (MK, Wanita, 40 tahun, dosen manajemen pemasaran)

\section{b. Kepercayaan Donatur pada Organisasi Filantropi}

Rasa percaya penyumbang pada organisasi filantropi tempat mereka menyumbangkan uangnya terlihat mendominasi hasil wawancara mendalam dengan para informan yang berupa donatur.

"Menurutku sih faktor kepercayaan yang terbangun pada hubungan antara aku dan organisasi di mana aku menyumbangkan uangku, 
adalah merupakan faktor yang utama yang membuatku setia pada organisasi tersebut. Kalau aku meyakini bahwa organisasi tersebut mampu menjalankan amanah dari para donatur, maka kita-kita donatur ini tidak akan segan-segan untuk menyumbangkan vang ke organisasi." ( $\mathrm{H}$, pria, 49 tahun, wiraswasta)

"Karena sudah cukup lama saya berhubungan dengan organisasi ini, dan saya merasa tidak pernah dikecewakan olehnya, maka rasa percaya pada organisasi ini semakin lama semakin besar. Sehingga tidak ada niatan sedikitpun untuk beralih ke organisasi lain." (E, wanita, 43 tahun, karyawati swasta)

"Organisasi filantropi itu kan organisasi yang menawarkan jasa, sekaligus organisasi non profit, jadi menurut saya kenapa saya memilih organisasi ini sebagai tempat saya mendonasikan vang saya adalah karena organisasi tersebut bisa saya percaya. Artinya bahwa uang yang saya donasikan di organisasi ini benar-benar dialokasikan ke kelompok masyarakat yang membutuhkan." (RS, pria, 39 tahun, karyawan swasta)

"Dengan didasari oleh rasa percaya itulah maka saya memiliki komitmen yang kuat untuk berelasi dengan organisasi/yayasan ini. Artinya bahwa saya merasa bangga dan merasa turut memiliki yayasan ini. Jadi kalau saya dimintai tolong oleh ketua dari yayasan ini, ya saya selalu bersedia membantunya dengan senang hati. Misalnya rata-rata setiap enam bulan sekali saya bersedia memeriksa gigi dan mulut dari anak-anak yatim piatu yang yang ada di yayasan ini." (SY, wanita, 30 tahun, dokter gigi)

"Saya juga merasa bahwa karena organisasi ini telah menunjukkan kinerja yang memuaskan selama kurang lebih delapan tahun ini, membuat saya percaya bahwa organisasi ini patut untuk diandalkan. Meskipun kadang saya juga merasa bahwa dalam beberapa hal saya masih merasa sedikit kurang puas dengan layanan yang diberikan oleh organisasi ini. Akan tetapi secara garis besar saya puas dengan organisasi ini." (DP, pria, 35 tahun, PNS)

"Kunci dalam menjalin hubungan adalah rasa percaya dari ke dua bela pihak. Apabila di antara ke duanya telah didasari rasa saling percaya, maka umumnya komitmen untuk terus menjalin hubungan akan terbentuk. Nah dengan kepercayaan dan komitmen inilah maka jalinan hubungan bisa dipastikan akan berlangsung lama, bahkan boleh dikatakan selamanya mbak, dengan catatan ke dua belah pihak tidak ada yang ingkar janji. Demikian juga dengan hubungan yang terjalin antara donatur dan organisasi filantropi ini, apabila rasa saling percaya, terutama rasa percaya donatur pada organisasi dapat dijaga dengan baik oleh organisasi, maka niscaya donatur ini akan menjadi donatur yang loyal pada organisasi filantropi tersebut. Dan demikian juga sebaliknya mbak...." (EPL, Wanita, 65 tahun, dosen)

"Mbaknya masih ingat dengan kejadian di Tangerang beberapa bulan yang lalu, ada seorang pendeta yang menjadi pengelola yayasan anak- 


\section{Jurnal Manajemen Teori dan Terapan Tahun 8. No. 3, Desember 2015}

anak kurang beruntung. Ternyata setelah berita penganiayaan yang dilakukan oleh pendeta tersebut pada anak-anak binaannya, maka dijamin tidak akan ada lagi donatur yang bersedia mendonasikan uangnya ke yayasan tersebut. Hal ini menunjukkan betapa pentingnya peran kepercayaan." (EPL, Wanita, 65 tahun, dosen)

Berikut ini adalah hasil wawancara mendalam dengan pengelola filantropi terkait dengan kepercayaan donatur.

"Rasa percaya dari para donatur pada organisasi filantropi adalah merupakan faktor utama yang membuat seorang donatur tidak beralih pada organisasi lain dalam mendonasikan uangnya." (H, pria, 52 tahun, pengelola organisasi filantropi / wiraswasta)

"Kalau merurut saya, trust tetap menjadi faktor penentu utama tetap terjalinnya hubungan antara donatur dan organisasi filantropi. Kemungkinan kepercayaan ini bisa terbentuk karena donatur merasa bahwa organisasi filantropi di mana dia memberikan sumbangannya telah bekerja dengan baik atau telah bekerja sesuai dengan harapannya, mungkin juga meraka merasa bahwa organisasi tersebut dapat diandalkan. Dengan trust ini, donatur akan setia pada organisasi, artinya tanpa kita minta untuk menyumbang vang, mereka dengan suka rela bahkan secara rutin, mereka memberikan sumbangan uang juga barang kepada kami." (L, wanita, 61 tahun, pengelola organisasi filantropi dan Dirut perusahaan)

Sementara itu, hasil wawancara mendalam dengan pakar/dosen manajemen pemasaran dipaparkan berikut ini:

"Dengan adanya kepercayaan dan komitmen relasional dari pelanggan akan memunculkan loyalitas bagi perusahaan/organisasi. Tanpa adanya rasa percaya di antara dua pihak yang berelasi, maka hubungan di antara ke dua belah pihak tidak akan bisa berjalan lama. Apapun bentuk relasinya, baik hubungan yang sifatnya formal maupun hubungan yang bersifat informal. Lebih-lebih lagi hubungan antara donatur dan organisasi filantropi, maka saya yakin kepercayaan akan berperan sentral, karena dalam berhubungan dengan organisasi ini. Tidak seperti hubungan antara seorang pelanggan dengan organisasi/perusahaan yang berorientasi pada keuntungan, di mana seorang pelanggan yang melakukan pembelian produk yang berupa barang, maka pelanggan tersebut akan mendapatkan sesuatu atau barang yang sifatnya adalah tangible, sehingga akan mudah bagi pelanggan tersebut untuk melakukan evaluasi atas kinerja perusahaan melalui barang yang dibelinya." (MK, Wanita, 40 tahun, dosen manajemen pemasaran)

"Hal ini akan sangat jauh berbeda dengan hubungan antara seorang penyumbang dengan organisasi filantropi. Seorang penyumbang tidak akan mendapatkan apapun meskipun dia telah memberikan sumbangan pada organsasi tersebut, hal ini karena pada prinsipnya 
organisasi filantropi adalah organisasi yang tidak berorientasi pada keuntungan dan produk yang ditawarkan adalah bersifat intangible, sehingga akan sangat sulit bagi donatur tersebut untuk melakukan evaluasi atas layanan yang telah dia terima dari organisasi tersebut." (ES, Wanita, 44 tahun, dosen manajemen pemasaran)

"Oleh karena itu, rasa percaya pada organisasi filantropi ini memiliki peran yang krusial, yang secara teoritis dan praktis akan meningkatkan komitmen dan loyalitas seorang penyumbang pada organisasi filantropi." (MK, Wanita, 40 tahun, dosen manajemen pemasaran)

"Dengan adanya kepercayaan dan komitmen yang tinggi dari penyumbang pada organisasi filantropi, maka sangat dimungkinkan akan menimbulkan tingkat loyalitas yang tinggi juga. Wujud dari loyalitas mereka mungkin berupa repurchase intention atau redonate intention, kerjasama dengan organisasi tersebut, word of mouth, menyumbang dengan jumlah vang yang lebih banyak, dan lain-lain... (ES, Wanita, 44 tahun, dosen manajemen pemasaran)

"Konsep relationship marketing merupakan suatu konsep yang sampai saat ini masih dianggap manjur untuk menjalin hubungan antara pelanggan dan organisasi/perusahaan. Dalam konsep tersebut, faktor kepercayaan adalah sebagai pemegang kendalinya. Demikian juga kalau diimplementasikan dalam hubungan antara donatur dengan organisasi filantropi." (ES, Wanita, 44 tahun, dosen Manajemen Pemasaran)

\section{b. Komitmen Ralasioanal Donatur pada Organisasi Filantropi}

Komitmen untuk berelasi dari para donatur pada organisasi juga nampak menjadi perhatian besar dari para informan, seperti narasi berikut ini yang memaparkan hasil wawancara mendalam dengan para informan.

"Kalau komitmen relasional itu menurutku sudah identik dengan loyalitas, karena kalau aku sudah komit untuk menyumbang di organisasi ini, berarti aku akan terus menyumbangkan uangku ke organisasi tersebut, dan kecil kemungkinan untuk beralih ke organisasi lain, meskipun ada teman yang mempengaruhi saya." ( $\mathrm{H}$, pria, 49 tahun, wiraswasta)

"Dengan didasari oleh rasa percaya itulah maka saya memiliki komitmen yang kuat untuk berelasi dengan organisasi/yayasan ini. Artinya bahwa saya merasa bangga dan merasa turut memiliki yayasan ini. Jadi kalau saya dimintai tolong oleh ketua dari yayasan ini, ya saya selalu bersedia membantunya dengan senang hati. Misalnya rata-rata setiap enam bulan sekali saya bersedia memeriksa gigi dan mulut dari anak-anak yatim piatu yang yang ada di yayasan ini." (SY, wanita, 30 tahun, dokter gigi)

"Bentuk-bentuk komitmen daya pada organisasi ini saya kira ya dengan saya memberikan sumbangan rutin setiap awal bulan setelah saya gajian, juga saya bebepa kali memberikan masukan dan saran ke organisasi ini 


\section{Jurnal Manajemen Teori dan Terapan Tahun 8. No. 3, Desember 2015}

demi kebaikan dan kelanggengan organisasi ini. Serta saya, maksud saya kantor saya juga beberapa kali saya ajak untuk baksos ke organisasi ini." (DP, pria, 35 tahun, PNS)

"Komitmen untuk tetap setia berelasi dengan organisasi filantropi tertentu umumnya terbangun karena donatur-donatur tersebut percaya pada organisasi, sehingga mereka enggan beralih ke organisasi lain dalam memberikan sumbangannya. Selain itu, para donatur yang memiliki kepedulian pada organisasi filantropi di mana mereka memberikan sumbangannya, donatur tadi akan setia pada organisasi, ya seperti kita yang setia pada istri dan keluarga kita." ( $\mathrm{H}$, pria, 52 tahun, pengelola organisasi filantropi / wiraswasta)

"Terkait dengan komitmen relasional, menurut saya hal ini bisa terbangun karena adanya rasa bangga menjadi bagian dari organisasi ini, sehingga umumnya mereka juga punya kepedulian yang tinggi pada organisasi. Sehingga seperti dalam hal apapun, misalnya kalau kita punya komitmen yang tinggi untuk menyelesaikan pendidikan kita, maka kita akan fokus dan bersungguh-sungguh dalam menjalankannya. Demikian juga dengan komitmen donatur pada organisasi, maka mereka juga akan dengan rela hati untuk memberikan donasi, juga tenaga, dan fikiran bagi organisasi." (L, wanita, 61 tahun, pengelola organisasi filantropi dan Dirut perusahaan)

\section{d. Loyalitas Donatur pada Organisasi Filantropi}

Hubungan yang terjalin dengan baik antara donatur dengan organisasi filantropi berbuah hasil yang manis yang bisa dituai oleh organisasi, yaitu berupa loyalitas, seperti nampak dalam hasil wawancara mendalam dengan para informan berikut ini.

"Karena sudah cukup lama saya berhubungan dengan organisasi ini, dan saya merasa tidak pernah dikecewakan olehnya, maka rasa percaya pada organisasi ini semakin lama semakin besar. Sehingga tidak ada niatan sedikitpun untuk beralih ke organisasi lain." (E, wanita, 43 tahun, karyawati swasta)

"Menurut saya, saya ini termasuk orang yang loyal pada organisasi ini, karena saya termasuk orang yang rutin menyumbang uang ke organisasi ini, bahkan beberapa kali saya juga pernah menyumbang barang." (E, wanita, 43 tahun, karyawati swasta)

"Saya baru satu tahunan menjadi donatur di organisasi filantropi ini, sebelumnya saya selalu berpindah-pindah organisasi dalam memberikan donasi. Selama setahun terakhir ini yang saya dapatkan dan rasakan dari organisasi ini cukup membuat saya puas. Artinya bahwa saya merasa yakin dan percaya bahwa organisasi ini bekerja sangat mumpuni. Kondisi inilah yang membuat saya pada akhirnya menjadi donatur tetap di organisasi ini selama setahun terakhir ini. Dan saya juga bertekad untuk terus mendonasikan uang saya di organisasi ini." (DP, pria, 35 tahun, PNS) 
"Adapun bentuk loyalitas saya pada organisasi ini adalah dengan memberikan sumbangan secara rutin, juga memberikan sumbangan yang lebih besar saat saya mendapat rezeki yang lebih besar dari biasanya. Selain itu saya juga selalu berusaha untuk mengajak orang lain, misalnya teman kerja, pacar saya, teman-teman kost saya untuk memberikan donasinya di organisasi di mana saya juga memberikan sumbangan." (SY, wanita, 30 tahun, dokter gigi)

"Saya juga merasa bahwa karena organisasi ini telah menunjukkan kinerja yang memuaskan selama kurang lebih delapan tahun ini, membuat saya percaya bahwa organisasi ini patut untuk diandalkan. Meskipun kadang saya juga merasa bahwa dalam beberapa hal saya masih merasa sedikit kurang puas dengan layanan yang diberikan oleh organisasi ini. Akan tetapi secara garis besar saya puas dengan organisasi ini." (DP, pria, 35 tahun, PNS)

"Bagi saya, loyalitas pada organisasi filantropi bisa dilihat dari bagaimana kualitas dan kuantitas danatur dalam memberikan sumbangannya pada organisasi tersebut...." (EPL, Wanita, 65 tahun, dosen)

"Bentuk loyalitas saya pada organisasi filantropi tidak hanya berupa rutinnya saya menyumbang di situ, akan tetapi saya juga ada keinginan untuk bekerja sama atau menyumbangkan tenaga dan pikiran saya apabila dibutuhkan di situ, meskipun tanpa bayaran Iho ya...." (RS, pria, 39 tahun, karyawan swasta)

"Menjaga loyalitas donatur pada organisasi adalah merupakan prioritas kami, karena kami meyakini bahwa menjaga relasi dengan mereka akan lebih menghemat biaya jika dibandingkan dengan upaya untuk mendapatkan donatur baru. Tetap menjaga silaturahmi dengan para donatur serta berusaha menjalan amanah yang mereka titipkan kepada kami adalah merupakan langkah-langkah untuk menjaga loyalitas donatur kami." (H, pria, 52 tahun, pengelola organisasi filantropi / wiraswasta)

"Upaya yang perlu saya lakukan untuk menjaga dan meningkatkan loyalitas donatur pada organisasi yang saya pimpin antara lain upaya untuk meningkatkan komunikasi dengan donatur serta tetap berusaha untuk berkinerja dengan baik, agar tidak mengecewakan para donatur." (L, wanita, 61 tahun, pengelola organisasi filantropi dan Dirut perusahaan)

"Hal ini akan sangat jauh berbeda dengan hubungan antara seorang penyumbang dengan organisasi filantropi. Seorang penyumbang tidak akan mendapatkan apapun meskipun dia telah memberikan sumbangan pada organsasi tersebut, hal ini karena pada prinsipnya organisasi filantropi adalah organisasi yang tidak berorientasi pada keuntungan dan produk yang ditawarkan adalah bersifat intangible, sehingga akan sangat sulit bagi donatur tersebut untuk melakukan evaluasi atas layanan yang telah dia terima dari organisasi tersebut." (MK, Wanita, 40 tahun, dosen manajemen pemasaran) 


\title{
Jurnal Manajemen Teori dan Terapan Tahun 8. No. 3, Desember 2015
}

\begin{abstract}
"Dengan adanya kepercayaan dan komitmen yang tinggi dari penyumbang pada organisasi filantropi, maka sangat dimungkinkan akan menimbulkan tingkat loyalitas yang tinggi juga. Wujud dari loyalitas mereka mungkin berupa repurchase intention atau redonate intention, kerjasama dengan organisasi tersebut, word of mouth, menyumbang dengan jumlah vang yang lebih banyak, dan lain-lain... (MK, Wanita, 40 tahun, dosen manajemen pemasaran)

"Adapun bentuk-bentuk loyalitas dalam konteks hubungan antara pelanggan dengan organisasi non profit seperti organisasi filantropi ini, bisa berupa niat atau perilaku menyumbang vang maupun barang yang berkelanjutan pada organisasi tersebut, mau memberikan sumbangan pemikiran maupun tenaga saat organisasi tersebut membutuhkannya, menginformasikan tentang hal-hal yang positif dari organisasi kepada masyarakat luas, dan sebagainya...." (ES, Wanita, 44 tahun, dosen Manajemen Pemasaran)
\end{abstract}

\section{Pembahasan}

Hasil penelitian ini mengindikasikan bahwa kepercayaan dan komitmen relasional yang merupakan inti konsep relationship marketing sesuai untuk diimplementasikan pada organisasi nonlaba, bahwa pada organisasi filantropi, variabel kepercayaan dan komitmen relasional berperan penting dalam upaya organisasi untuk menjalin relasional dengan para penyumbang Seperti yang dikemukakan oleh Berry (1983) dalam Morgan dan Hunt (1994) bahwa relationship marketing merupakan strategi untuk menarik, memelihara, dan mempererat hubungan dengan pelanggan. Dengan demikian, kontribusi yang bisa diberikan dari hasil penelitian ini pada teori pertukaran sosial dan konsep relationship marketing adalah teori dan konsep tersebut tidak hanya sesuai untuk hubungan yang berorientasi keuntungan saja. Akan tetapi, konsep tersebut juga bisa diimplementasikan pada hubungan yang tidak berorientasi keuntungan.

Temuan dalam penelitian ini sesuai dengan argumentasi Naskrent dan Siebelt (2011). Mereka berpendapat bahwa komitmen sebagai variabel inti dalam memengaruhi penyumbang untuk menyumbang kembali. Selain itu, hal tersebut juga mengakibatkan penyumbang memiliki keinginan yang lebih kuat untuk melanjutkan relasi pertukaran. Temuan ini juga mendukung hasil riset sebelumnya yang dilakukan oleh Dwyer et al. (1987) dan Waters (2008), yang mendapat temuan bahwa komitmen relasional memengaruhi niat penyumbang untuk menyumbang kembali. Hal ini mengisyaratkan bahwa komitmen sebagai variabel yang berperan penting dalam menjaga loyalitas dalam suatu hubungan. Dengan demikian, temuan penelitian ini sesuai dengan teori 
pertukaran sosial. Teori pertukaran sosial menyatakan bahwa orang diharapkan akan memiliki komitmen pada relasi sosialnya, kelompoknya, dan organisasinya (Blau, 1964).

Hasil riset ini sejalan dengan temuan riset sebelumnya (Anderson dan Narus, 1990; Moorman et al., 1992; Morgan dan Hunt, 1994; Doney and Cannon, 1997) yang memaparkan bahwa kepercayaan berpengaruh pada kerjasama. Kepercayaan yang telah terbangun di benak para penyumbang merupakan modal yang sangat penting bagi organisasi filantropi. Hal tersebut karena kercayaan inilah yang menjadikan organisasi dapat mengarahkan para penyumbang untuk bersedia bekerjasama dengan organisasi. Sesuai dengan yang dikemukakan oleh Saavedra, Smith, dan Reed-Tsochas (2010) bahwa seorang penyumbang akan memutuskan bersedia bekerjasama atau tidak didasarkan pada gambaran yang mereka terima dan strategi penilaian mereka.

Rasa percaya yang telah melekat di benak para penyumbang dapat menimbulkan niat mereka untuk menyumbang kembali ke organisasi filantropi. Hal ini mendukung temuan-temuan riset sebelumnya bahwa penyumbang dengan tingkat kepercayaan tinggi akan memberikan sumbangannya kembali di waktu mendatang (Garbarino dan Johnson, 1999; Waters, 2008; Camarero dan Garrido, 2011; Naskrent dan Siebelt, 2011).

Loyalitas dari para donatur yang salah satunya berupa keinginan atau niat untuk menyumbang kembali menjadi hal penting bagi organisasi filantropi, karena dengan adanya niat untuk menyumbang kembali dari para penyumbang inilah maka keberadaan dan keberlangsungan organisasi akan tetap terjaga. Oleh karena itu, organisasi perlu untuk terus mempertahankan kepercayaan penyumbang pada orginisasi, agar mereka tetap berniat untuk menyumbang kembali di masa mendatang. Hal ini didasari oleh kenyataan, bahwa kepercayaan adalah inti dari seluruh perelasian. Kepercayaan ada apabila salah satu pihak yang berasal dari mitra pertukaran mempunyai keandalan dan integritas (Morgan dan Hunt, 1994). Demikian juga dengan Zaheer, McEvily, dan Perrone (1998) mengungkapkan mengenai premis utama teori pertukaran relasional. Teori tersebut menjelaskan bahwa relasi personal menghasilkan kepercayaan dan mencegah perilaku oportunistik. Selain itu, konseptualisasi kepercayaan lebih sebagai harapan daripada sebagai keyakinan yang mencerminkan suatu antisipasi ketidakpastian mengenai rujukan perilaku di masa mendatang. 


\section{Jurnal Manajemen Teori dan Terapan \\ Tahun 8. No. 3, Desember 2015}

Hasil wawancara mendalam dengan para informan menunjukkan bahwa para penyumbang yang merasa berterima kasih pada organisasi dapat menyebabkan loyalitas pada organisasi. Dengan demikian, hasil penelitian ini berbeda dengan temuan riset yang dilakukan oleh Palmatier et al. (2009) untuk studi kedua (survei) di organisasi yang berorientasi laba, yang menunjukkan bahwa rasa terima kasih tidak mempengaruhi loyalitas.

Dalam organisasi yang berorientasi laba maupun organisasi yang tidak berorientasi laba, juga organisasi yang menghasilkan produk yang berupa barang, lebih-lebih lagi organisasi yang menghasilkan produk yang berupa jasa, keberadaan loyalitas sangat penting. Riset ini dilakukan pada setting organisasi yang tidak berorientasi laba dengan produk yang ditawarkan adalah berupa jasa, sehingga apa yang diterima oleh mitra relasi adalah sesuatu yang sifatnya intangible. Oleh karena itu, peran kepercayaan, rasa terima kasih, dan komitmen relasional sangat vitas untuk membentuk loyalitas para penyumbang pada organisasi filantropi.

\section{KESIMPULAN}

Dari hasil wawancara mendalam dengan para informan menunjukkan bahwa kepercayaan dan komitmen memegang peran yang sangat penting dalam konteks hubungan yang terjadi antara donatur dengan organisasi filantropi, di mana para donatur memberikan donasinya. Temuan penelitian ini mendukung teori pertukaran sosial (Thibaut dan Kelley, 1959; Blau, 1964; Homans, 1968), dan mendukung kosep relationship marketing (Morgan dan Hunt, 1994). Konsep tersebut mendudukan variabel kepercayaan dan komitmen relasional sebagai variabel yang berperan sentral dalam suatu hubungan yang terjalin di antara individu dan organisasi. Hasil riset ini menguatkan temuan riset yang dilakukan oleh Sargeant dan Lee (2004) yang mengungkapkan bahwa kepercayaan dan komitmen relasional berdampak pada perilaku dari para penyumbang di sektor amal. Hal ini juga sesuai dengan yang dikemukakan oleh Kumar (1996) dalam Luo dan Donthu (2007), hubungan yang dipercaya akan meningkatkan kemungkinan terhadap orientasi jangka panjang dalam pertukaran.

Dari hasil wawancara mendalam menunjukkan bahwa rasa terima kasih yang ada di benak para donatur dapat meningkatkan kepercayaan mereka pada organisasi filantropi di mana selama ini mereka memberikan sumbangannya. Rasa terima kasih atas apa yang telah dilakukan oleh organisasi filantropi yang 
umumnya dirasakan oleh para donatur juga mengindikasikan menjadi faktor pendorong loyalitas mereka pada organisasi tersebut. Bentuk-bentuk loyalitas yang mereka lakukan antara lain adalah berupa kemauan untuk terus memberikan sumbangan di organisasi filantropi, apabila mendapat rezeki yang lebih banyak maka jumlah donasi yang mereka berikan juga akan ditingkatkan, tidak akan beralih ke organisasi lainnya, rela/berkenan untuk memberikan sumbangan tenaga dan pikiran mereka apabila organisasi membutuhkannya, tidak sungkan-sungkan untuk memberikan masukan demi kebaikan dan masa depan organisasi tersebut, serta melakukan word of mouth (WOM) tentang organisasi filantropi tersebut. Keberadaan loyalitas bagi organisasi filantropi sangat kruisial karena akan sangat terkait dengan masa depan dari organisasi tersebut.

\section{Saran}

Kontribusi yang bisa diberikan dari hasil studi ini pada teori pertukaran sosial dan konsep relationship marketing adalah bahwa teori dan konsep tersebut tidak hanya sesuai untuk hubungan yang berorientasi keuntungan semata. Akan tetapi teori dan konsep tersebut juga sesuai untuk diimplementasikan pada hubungan yang tidak berorientasi pada keuntungan. Blau (1964) menjelaskan pertukaran sosial sebagai tindakan sukarela individu, yang dimotivasi oleh manfaat yang mereka harapkan untuk bisa mereka peroleh, dan biasanya didapatkan dari pihak lain. Dalam teori pertukaran sosial (Thibaut dan Kelley, 1959; Blau, 1964; Homans, 1968) dan dalam konsep relationship marketing (Morgan dan Hunt, 1994), diungkapkan bahwa kepercayaan dan komitmen berperan sentral dalam suatu pertukaran.

Penelitian ini dilakukan pada organisasi filantropi yang bersifat umum, mencakup filantropi di berbagai bidang antara lain kesehatan, keagamaan, pendidikan, dan sosial. Riset mendatang disarankan untuk dilakukan pada organisasi filantropi yang bersifat khusus, misalnya organisasi keagamaan saja, organisasi kesenian saja, organisasi pendidikan saja, dan sebagainya.

\section{REFERENSI}

Anderson, J. C. and J. A. Narus (1990), "A Model of Distributor Firm and Manufacturer Firm Working Partnerships," Journal of Marketing, Vol. 54 (January), 42-58.

Blau, P. M. (1964), Exchange and Power in Social Life, New York: John Wiley \& Sons, Inc. 


\section{Jurnal Manajemen Teori dan Terapan Tahun 8. No. 3, Desember 2015}

Camarero, C. and M. J. Garrido (2011), "Incentives, Organisational Identification, and Relationship Quality Among Members of Fine Arts Museums," Journal of Service Management, Vol. 22, No. 2, 266-287.

Cropanzano, R. and M. S. Mitchell (2005), "Social Exchange Theory: An Interdisciplinary Review," Journal of Management, Vol. 31 (December), No. 6, 874-900.

Dewani, P. P. and P. K. Sinha (2012), "Gratitude: An Emotional Approach in Business Relationship," Research Journal of Business Management, Vol. 6, No. $1,1-11$.

Doney, M. P. and J. P. Cannon (1997), "An Examination of The Nature of Trust In Buyer-Seller Relationships," Journal of Marketing, Vol. 61 (April), No. 2, 35-51.

Dwyer, F. R.; P. H. Schurr; and S. Oh (1987), "Developing Buyer-Seller Relationships," Journal of Marketing, Vol. 51 (April), No. 2, 11-27.

Ganesan S. (1994), "Determinants of Long-Term Orientation in Buyer-Seller Relationships," Journal of Marketing, Vol. 58, No. 2 (April), 1-19.

Garbarino, E. and M. S. Johnson (1999), "The Different Roles of Satisfaction, Trust, and Commitment in Customer Relationships." Journal of Marketing, Vol. 63 (April), No. 2, 70-87.

Gouldner, A. W. (1960), "The Norm of Reciprocity: A Preliminary Statement," American Sociological Review, Vol. 25 (April), No. 2, 161-178.

Homans, G. C. (1968), Social Behaviour Its Elementary Forms, Third impression, Great Britain: Latimer Trend \& Co Ltd.

Houston, F. S. and J. B. Gassenheimer (1987), "Marketing and Exchange," The Journal of Marketing, Vol. 51 (October), No. 4, 3-18.

Luo, X., and N. Donthu (2007), "The Role of Cyber-Intermediaries: A Framework Based on Transaction Cost Analysis, Agency, Relationship Marketing and Social Exchange Theories," Journal of Business \& Industrial Marketing, Vol. 22, No. 7, 452-458.

McCort, J. D. (1994), "A Framework for Evaluating The Relational Extent of A Relationship Marketing Strategy: The Case of Nonprofit Organizations," Journal of Direct Marketing, Vol. 8 (Spring), No. 2, 53-65.

Moorman, C.; G. Zaltman, and R. Deshpande (1992), "Relationships Between Providers and Users of Marketing Research: The Dynamics of Trust Within and Between Organizations," Journal of Marketing Research, Vol. 29 (August), 314328.

Morgan, R. M. and S. D. Hunt (1994), "The Commitment-Trust Theory of Relationship Marketing," Journal of Marketing, Vol. 58 (July), No. 3, 20-38.

Naskrent, J. and P. Siebelt (2011), "The Influence of Commitment, Trust, Satisfaction, and Involvement on Donor Retention," International Society for Third-Sector Research, DOI 10.1007/s1 1266-010-9177-x, Published Online: 05 January 2011.

Palmatier, R. W.; C. B. Jarvis; J. R. Bechkoff; and F. R. Kardes (2009), "The Role of Customer Gratitude in Relationship Marketing," Journal of Marketing, Vol. 73 (September), 1-18.

Rusbult, C. E.; J. M. Martz; and C. R. Agnew (1998), "The Investment Model Scale: Measuring Commitment Level, Satisfaction Level, Quality of Alternatives, and Investment Size," Personal Relationships, Vol. 5, 357-391.

Saavedra S.; D. Smith; and F. Reed-Tsochas (2010), "Cooperation under Indirect Reciprocity and Imitative," PLOS ONE, Vol. 5 (October), Issue 10, e13475.

Thibaut, J.W. and H. H. Kelley (1959), The Social Psychology of Groups, New York: John Wiley \& Sons, Inc. 
Venable, B. T.; G. M. Rose; V. D. Bush; and F. W. Gilbert (2005), "The Role of Brand Personality in Charitable Giving: An Assessment and Validation," Journal of the Academy of Marketing Science, Vol. 33, No. 3, 295-312.

Waters, R. D. (2008), "Applying Relationship Management Theory to The Fundraising Process for Individual Donors," Journal of Communication Management, Vol. 12, No. 1, 73-87.

Zaheer A.; B. McEvily; and V. Perrone (1998), "Does Trust Matter? Exploring the Efects of Interorganizational and Interpersonal Trust on Performance," Organization Science, Vol. 9, No. 2 (Mar.-Apr.), 141-159.

http://www. filantropi.or.id/index2.php?option=com_content\&do_pdf=1 \&id=62, diakses 3/3/ 2014.

http://sekolahfundraising.wordpress. com, diakses 5/3/2014. 